\title{
Peertechz
}

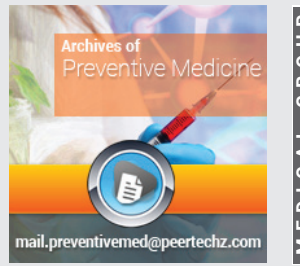

\section{Evaluation of Factors affecting voluntary blood donation in South-South Nigeria: Focus on Akwa Ibom State}

\author{
Grace Etete Peters*and Nnabuike Inya Oko \\ 'Department of Nursing Services, University of Uyo Teaching Hospital, Uyo, Akwa Ibom, Nigeria \\ 2Department of Administration, University of Uyo Teaching Hospital, Uyo, Akwa Ibom, Nigeria
}

Received: 13 September, 2021

Accepted: 24 September, 2021

Published: 25 September, 2021

*Corresponding author: Grace Etete Peters, PhD, Department of Nursing Services, University of Uyo Teaching Hospital, Uyo, Akwa Ibom, Nigeria, Tel: +2348036846609; Email: graceepeteters@yahoo.com

Keywords: Education/awareness; Voluntary blood donation; Culture and socio-cultural factors

Copyright: @ 2021 Peters GE, et al. This is an openaccess article distributed under the terms of the Creative Commons Attribution License, which permits unrestricted use, distribution, and reproduction in any medium, provided the original author and source are credited

https://www.peertechz.com

\section{Check for updates}

\section{Abstract}

Background: The sudden increase in demand for blood transfusion globally without the corresponding increase in voluntary blood supply (donation) has become a serious health problem. Countries across the world are facing serious problem of blood scarcity. Therefore this study was carried out to evaluate the socio- cultural factors affecting voluntary blood donation in Akwa Ibom State.

Methods: A survey research design was adopted for the study and was carried out from January to May 2017. Three hundred respondents were purposely selected for the study from the three Senatorial districts using simple random techniques. Data were collected, collated and analyzed into frequencies and percentages and were also presented in tables.

Results: The findings of the study revealed that majority (91.5\%) people have good knowledge of voluntary blood donation due to the level of awareness and also view the exercise as important even without reward (remuneration) from recipients despite the influence of some socio-cultural factors such as culture, religion among others.

Conclusion: It was therefore concluded that socio-cultural barriers to voluntary blood donation still exist, thereby giving room for misconception. Therefore, there should be intensified health education using various methods including health workers, print media and community leaders on the benefit of voluntary blood donation. This will help to correct some misconceptions on blood donation as there are people who still believe in the dictates of their religious and cultural practices as it relates to blood donation and its attendant health implication.

\section{Introduction}

The rise in human life expectancy and implementing new and aggressive surgical and therapeutic methods have increased the demand for blood and blood products in most countries. Blood is the most donated tissue in medical practice and a veritable tool in many live-saving situations when used judiciously. Blood donation occurs when a person voluntarily has blood drawn and used for transfusions and/or made into biopharmaceutical medications by a process called fractionation (separation of whole-blood components). Blood is so important to the human body that without it, existence is completely impossible [1]. Health systems throughout the world need adequate supply of blood for their proper functioning. In Sub-Saharan Africa, where anemia resulting from malaria, sickle cell disease, road traffic accidents etc, is common, blood is needed even more. However, inadequate blood donation in Sub-Saharan Africa including Nigeria is a major public health problem.

The importance of voluntary blood donation has long been recognized on the global health agenda at the highest political level. As long ago as 1975, the World Health Assembly urged its Member States to promote the development of national blood services based on the voluntary non-remunerated donation of blood. It also called on them to enact effective legislation governing the operation of blood services and to take other actions necessary to promote and protect the health of blood donors and the recipients of blood and blood products among others [2]. 
Voluntary blood donation helps to assist persons in need of blood, accident victims, cancer patients, sickle cell anaemia patients and pregnant women in labour among others. According to the World Health Organization [3], the most recent available data on global supply of blood showed that in 2008 forty-three countries in the African region, home to about $12 \%$ of the global population, reported collecting only 4 million units of blood or $4.3 \%$ of global blood donations.

The Federal Ministry of Health in Nigeria in 2007 reported that the country's National blood transfusion service is making an effort to retain its voluntary donors by giving incentives such as free blood tests (blood group, hemoglobin genotype, HIV/ hepatitis) to donors, allowing the immediate family of volunteers to use blood without replacement and giving gift items such as certificates, T-shirts, hematinic, refreshments and badges.

Despite these efforts, Obinna, Amusat and Udemba [4] lamented that with less than 10 percent of Nigerians donating blood voluntarily, the country is currently reeling under the onslaught of serious shortage of safe blood and blood products, even as opinion leaders in the country, particularly, those in the rural communities have been urged to lead by example by donating blood voluntarily. Nigeria is currently faced with a situation, whereby about 60 percent of all blood donations are from commercial donors and 30 percent from family replacement. About 1,130,000 units of blood are collected annually in the country through the various types of donations as against $1,336,000$ estimates of blood units required. The deficit has resulted in numerous preventable deaths especially among women and children and people living with certain diseases [4].

This development has attracted the attention of international health agencies such as the World Health Organization and the International Federation of Red Cross and Red Crescent Societies with the aim of promoting voluntary blood donation among the people to guarantee safe, adequate and timely supply of blood to save human life.

Particularly in Akwa Ibom State, voluntary blood donation has not attracted much attention as there is no known coordinated programme in this direction. Also, socio-cultural factors such as culture and education/awareness continue to have a negative impact on the knowledge and attitude of the people towards voluntary blood donation which has contributed to too many preventable deaths causing impaired physical, psychological and social functioning of those affected and equally serious psychological, social and economic consequences for their families. It is against this background that this study seeks to examine the extent to which cultural belief, religion and level of education/awareness of the people affect voluntary blood donation activity in Akwa Ibom State, Nigeria. Moreover, no concerted efforts have been made in the past by previous researchers in the state to focus on these factors which may impede a smooth voluntary blood donation drive in the State. This study is highly relevant and justified by the fact that these factors so highlighted could be incorporated into the various awareness programme that will be designed to curb any negative influence to voluntary blood donation in the state

\section{Methodology}

\section{Study design}

The research design for the study was the survey design carried out from January to May, 2017

\section{Study location}

The study was carried out in the three Senatorial Districts in Akwa Ibom State.

\section{Study population}

The population of the study consisted of all voluntary blood donors (male and female) in all Local Government Areas(LGA) of Akwa Ibom State. The total population of the state based on 2006 population census is $3,920,208$ (males - 2044510 and females - 1875698).

\section{Sample size}

The total numbers of three hundred voluntary blood donors were selected for the study. The researcher conveniently selected all of them because they all gave their consent to participate in the study. Efforts were made to ensure that male and female donors were covered

\section{Sampling techniques}

Participants were purposively selected using simple random sampling techniques. The questionnaires were administered to participants in villages, churches and market places. Out of the three hundred copies of questionnaire administered; only two hundred and eighty five were used for analysis. This is so because ten of the questionnaires were not returned while five were wrongly completed and were therefore considered unfit to be included for analysis giving a response rate of $95 \%$.

\section{Method of data analysis}

The study adopted quantitative method of analysis. Data analysis were done using quantitative data analysis tools. The data were presented in percentages and frequencies and were also presented as tables

\section{Consent to participate}

Informed written consent was taken from study participants. Personal identifiers were not used and information obtained was treated confidentially. Ethical considerations were given utmost considerations in all aspects of the research.

\section{Results}

Majority of the respondents (50.9\%) were in the age bracket of 26-30 years. Higher number of the respondents (50) didn't know their blood group. Greater numbers (58.9\%) of the respondents were males. Majority $(66 \%)$ of the respondents were single. Majority (36.8\%) of the respondents attained 
secondary education. Majority (42\%) of the respondents were Pentecostal by faith Tables 1,2.

Majority (91.9\%) of the respondents have seen or heard messages about blood donation through television/radio. All the respondents were aware that they can donate blood to another person. A higher percentage $(66.7 \%)$ affirmed that they have blood donation centers in their L.G.A. Majority (95.4\%) of the respondents agreed that blood donation was necessary. Greater number of respondents $(85.6 \%)$ said the reason for donation of blood was to save lives Table 3 .

Majority of the respondents $(51.2 \%)$ disagreed that their culture forbids blood donation. Greater number of the respondents $(62.1 \%)$ strongly disagreed that blood donated

Table 1: Demographic characteristics of respondents (voluntary donors) in Akwa Ibom State $(n=92)$.

\begin{tabular}{|c|c|c|}
\hline Variables & Frequency & Percentage \\
\hline \multicolumn{3}{|l|}{ Age group } \\
\hline $20-25$ & 54 & 18.9 \\
\hline $26-30$ & 145 & 50.9 \\
\hline $31-35$ & 72 & 25.3 \\
\hline 36 and above & 14 & 4.9 \\
\hline Total & 285 & 100 \\
\hline \multicolumn{3}{|l|}{ Blood groups of respondents } \\
\hline Don't know & 145 & 50.9 \\
\hline $0+$ & 90 & 31.6 \\
\hline Other groups (specify) & 50 & 17.5 \\
\hline Total & 285 & 100 \\
\hline \multicolumn{3}{|l|}{ Sex } \\
\hline Male & 168 & 58.9 \\
\hline Female & 117 & 41.1 \\
\hline Marital status & 285 & 100 \\
\hline Single & 188 & 66 \\
\hline Married & 84 & 29.4 \\
\hline Divorced & 8 & 2.8 \\
\hline Widowed & 5 & 1.8 \\
\hline Total & 285 & 100 \\
\hline \multicolumn{3}{|l|}{ Level of education } \\
\hline No formal education & 38 & 13.3 \\
\hline Primary education & 65 & 22.8 \\
\hline Secondary education & 105 & 36.8 \\
\hline Post secondary education & 77 & 27.1 \\
\hline Total & 285 & 100 \\
\hline \multicolumn{3}{|l|}{ Religious Status } \\
\hline Catholic & 65 & 22.8 \\
\hline Orthodox & 80 & 28.1 \\
\hline Pentecostal & 120 & 40 \\
\hline Islam & 5 & 1.8 \\
\hline 'Traditional worshiper & 15 & 5.3 \\
\hline Total & 285 & 100 \\
\hline
\end{tabular}

Source: Fieldwork, 2017
Table 2: Education/awareness and voluntary blood donation $(n=285)$.

\begin{tabular}{|c|c|c|}
\hline Statement & $\begin{array}{l}\text { Frequency } \\
\text { Yes }(\%)\end{array}$ & $\begin{array}{l}\text { Percentage } \\
\quad \text { No (\%) }\end{array}$ \\
\hline $\begin{array}{l}\text { Have you ever seen or heard messages about blood } \\
\text { donation? }\end{array}$ & 262 (91.9) & $23(8.1)$ \\
\hline \multicolumn{3}{|l|}{ If yes, where did you receive that information from? } \\
\hline Health workers & 58 & 22.1 \\
\hline TV/ Radio & 115 & 43.9 \\
\hline Teachers/ Lecturers & 40 & 15.3 \\
\hline Friends & 30 & 11.5 \\
\hline Others (specify) & 19 & 7.2 \\
\hline $\begin{array}{c}\text { Are you aware that you can donate blood to another } \\
\text { person? }\end{array}$ & $285(100)$ & 0 \\
\hline Are there any blood donation centers in your L.G.A & $190(66.7)$ & $95(33.3)$ \\
\hline Do you think that blood donation is necessary? & $272(95.4)$ & $13(4.6)$ \\
\hline \multicolumn{3}{|l|}{ Reason for donation of blood? } \\
\hline To save lives & 244 & 85.6 \\
\hline To sell and make money & 18 & 6.3 \\
\hline To hear compliments and praise from & 10 & 3.5 \\
\hline \multicolumn{3}{|l|}{ others } \\
\hline Self use when I need blood myself & 2 & 0.7 \\
\hline Having free blood tests & 11 & 3.9 \\
\hline Other reasons & 0 & 0 \\
\hline
\end{tabular}

Table 3: Culture and voluntary blood donation $(n=285)$.

\begin{tabular}{|c|c|c|c|c|}
\hline Questions & $\begin{array}{c}\text { Strongly } \\
\text { Agree } \\
\mathbf{n}(\%)\end{array}$ & $\begin{array}{c}\text { Agree } \\
\mathbf{n}(\%)\end{array}$ & $\begin{array}{c}\text { Disagree } \\
\mathbf{n}(\%)\end{array}$ & $\begin{array}{c}\text { Strongly } \\
\text { Disagree } \\
\mathbf{n}(\%)\end{array}$ \\
\hline My culture forbids blood donation. & $26(9.1)$ & $31(10.9)$ & $146(51.2)$ & $82(28.8)$ \\
\hline $\begin{array}{c}\text { People believe that blood donated } \\
\text { could be exposed to witchcraft. }\end{array}$ & $14(4.9)$ & $29(10.2)$ & $65(22.8)$ & $177(62.1)$ \\
\hline $\begin{array}{c}\text { In my culture donating of blood could } \\
\text { reduces one's life span. }\end{array}$ & $35(12.3)$ & $13(4.6)$ & $79(27.7)$ & $158(55.4)$ \\
\hline $\begin{array}{c}\text { In my community the gods are } \\
\text { consulted before donating blood. }\end{array}$ & $13(4.6)$ & $15(5.2)$ & $70(24.6)$ & $187(65.6)$ \\
\hline $\begin{array}{c}\text { In my family we do not donate blood to } \\
\text { people who are not familiar to us. }\end{array}$ & $3(1.1)$ & $7(2.4)$ & $60(21.1)$ & $215(75.4)$ \\
\hline Source: Fieldwork, 2017 . & & & & \\
\hline
\end{tabular}

Source: Fieldwork, 2017

could be exposed to witchcraft. Majority of the respondents $(55.4 \%)$ strongly disagreed that donating of blood could reduce one's life span. Majority of the respondents (65.6\%) strongly disagreed that gods are consulted before donating blood. Majority of the respondents $(75.4 \%)$ strongly disagreed that they do not donate blood to people who are not familiar to them Table 4.

Majority of the respondents $(50.2 \%)$ strongly disagreed that in their religion blood donation was disrespectful of one's ancestors. Majority of the respondents (65.3\%) strongly disagreed that their religion preaches about natural way of regaining blood only. Majority of the respondents (60.4\%) disagreed that their religion forbids donation of blood. Higher percentage of respondents $(66.7 \%)$ strongly disagreed their religion sees blood donation as a sin against God .However, 
Table 4: Religion and voluntary blood donation $(n=285)$.

\begin{tabular}{|c|c|c|c|c|}
\hline Questions & $\begin{array}{c}\text { Strongly } \\
\text { Agree } \\
\mathbf{n}(\%)\end{array}$ & $\begin{array}{c}\text { Agree } \\
\mathbf{n}(\%)\end{array}$ & $\begin{array}{c}\text { Disagree } \\
\mathbf{n}(\%)\end{array}$ & $\begin{array}{c}\text { Strongly } \\
\text { Disagree } \\
\mathbf{n}(\%)\end{array}$ \\
\hline $\begin{array}{c}\text { It is a belief in my religion that blood } \\
\text { donation is disrespectful of one's } \\
\text { ancestors. }\end{array}$ & $25(8.8)$ & $42(14.7)$ & $75(52.3)$ & $143(50.2)$ \\
\hline $\begin{array}{c}\text { My religion preaches about natural way } \\
\text { of regaining blood only. }\end{array}$ & $14(4.9)$ & $27(9.4)$ & $58(20.4)$ & $186(65.3)$ \\
\hline $\begin{array}{c}\text { My religion forbids donation of blood. } \\
\text { My religion sees blood donation as a sin }\end{array}$ & $16(5.6)$ & $21(7.4)$ & $172(60.4)$ & $76(26.6)$ \\
\hline $\begin{array}{c}\text { against God. } \\
\text { My religion has a strong impact on } \\
\text { voluntary blood donation. }\end{array}$ & $168(58.9)$ & $72(25.3)$ & $20(7)$ & $25(8.8)$ \\
\hline
\end{tabular}

Source: Fieldwork, 2017

greater percentage of respondents (58.9\%) strongly agreed their religion has strong impact on voluntary blood donation.

\section{Discussion}

The majority (91.9\%) of the respondents in this study have seen or heard messages about blood donation through television/radio. All the respondents were aware that they can donate blood to another person and they affirmed that they have blood donation centers in their Local Government Areas. Majority (95.4\%) of the respondents agreed that blood donation was necessary and meant to save lives. This could be attributed to the level of education/awareness among respondents on voluntary blood donation in the areas. This is confirmed by World Health Organization [5] which maintained that without information, most people will simply remain unaware of the blood transfusion service and the need for blood donation. It argued that without education and motivational activities, few will be sufficiently self-motivated to find out how they can donate their blood. Communication is at the core of a successful and sustainable voluntary blood donor programme. Also, Dubey, et al. [6] in their study of knowledge, attitude and beliefs of people in North India regarding blood donation found that television was the most effective medium of communication for raising awareness about blood donation. Jemberu, et al. [7] in their study on knowledge, attitude and practice towards blood donation and associated factors among adult in Debre Markos town, Northwest Ethiopia revealed that health education of the public was associated with participation in blood donation. While listening to radio broadcasts was also found to be a predictor of knowledge on blood donation. Waheed, et al. [8] in their study found that lack of information and understanding about the need and process of blood donation, inadequate knowledge regarding the benefit of blood donation, misconceptions and perceived negative health effects caused by donation, and negative attitudes were the most frequently revealed reasons that discourage individuals from donating blood. Ojonugwa [1] argued that to cure the ignorance associated with blood transfusion, there are several strategies recommended by the World Health Organization (WHO) which include community sensitization and mobilization; one of the biggest strategies to increase the awareness about blood transfusion. World Health Organization [9] maintained that, without information, most people will simply remain unaware of the blood transfusion service and the need for blood donation. It argued that without education and motivational activities, few people will be sufficiently self-motivated to find out how they can donate their blood. Lacetera and Macis [10] posited that the media can also play a major role in reinforcing blood donation. This can be done through newspapers, radio, television, or online media in the form of advertisements or news stories, which may spur people to donate blood.

The result of the study also revealed that cultural factors do not affect voluntary blood donation in the area as majority of the respondents believed that cultural practices do not forbid blood donation nor does it expose the donor to witchcraft. Majority of the respondents strongly disagreed that donating blood could reduce one's life span and that the gods are not consulted before donating blood. This is in contrast with the views of Bir Singh, et al. [11] who observed that in India, blood to the lay people appears to be a precious commodity in short supply, where malaise or weakness or fatigue after a hard day work was perceived to be due to "knoon ki kami" and over half of all no donors cited that culturally indigenous fear, 'knoon ki kami'or having a volumetric deficiency of blood as the reason for non donation. Shan, et al. [12] lamented that misconceptions about the effects of blood donation are widespread, even among educated persons worldwide. However, most false beliefs are found in the developing countries. Traditional Chinese cultural belief harbor strong misconceptions exaggerating the harmful effect of blood donation. A common belief about blood donation in China is that it causes a loss in vitality or it may be disrespectful of one's ancestor. Salaudeen, et al. [13] argued that in many countries, there are cultural attitudes that limit acceptance to blood donation activities, and governments and other institutions do little to counteract these attitudes which negatively affect the knowledge and attitude of the people towards voluntary blood donation. Among the Indian adults, customs related to culture were associated with not donating blood [14].

The result of the study further revealed that religion does not negatively affect voluntary blood donation. Majority of the respondents strongly disagreed that in their religion blood donation was disrespectful of one's ancestors and that their religion accepts such practice. This is in conflict with the study carried out in 28 provinces of Iran by Hassan, Nasim and Fariba [15] which revealed that after altruism, religious beliefs are the most frequent positive motivation for blood donation among Iranians. Maghullu [16] argued that the Holy month of Ramadan is another important occasion affecting blood donation drive. During Ramadan, blood banks usually face blood shortages. This is due to the belief among people, which presume that blood donation may invalidate their fast. Another reason is that donating blood during fasting may cause weakness and blood donors may be forced to break their fast. Abdel, et al. (2011) in a research on the attitude to blood donation in Saudi Arabia observed that religion is deeply rooted in the Saudi society and there is little doubt that it is a major motivating factor for the local population to donate blood, as $71 \%$ of the donors in the current study believe that blood donation is a religious duty. Abderrahman and Saleh [17] in a 
study investigating knowledge and attitudes of blood donors and barriers concerning blood donation in Jordan revealed a positive association between religion and attitudes related to blood donation. Wikipedia [18] reported that Jehovah's Witnesses believe that the Bible prohibits ingesting blood and that Christians should not accept blood transfusions or donate or store their own blood for transfusion. The belief is based on an interpretation of scripture that differs from that of other Christian denominations. The Watchtower [19] reported that Witnesses' refusal of transfusions of whole blood or its four primary components-red cells, white cells, platelets and plasma-is a non-negotiable religious stand and that those who respect life as a gift from God do not try to sustain life by taking in blood, even in an emergency [20].

\section{Conclusion}

Based on the results and findings of the study, it was observed that the people have good knowledge of voluntary blood donation due to the level of education/awareness and also view the exercise as important and meant to save lives despite the influence of some socio-cultural factors such as culture, religion among others.

Therefore, there should be intensified health education using various methods including health workers, print media and community leaders on the benefit of voluntary blood donation. This will help correct some misconceptions on blood donation as there are people who still believe in the dictates of their religious and cultural practices as it relates to blood donation and its attendant health implications.

Also, there is need to encourage and motivate people on voluntary blood donation through provision of free medical services to voluntary donors as well as making blood donation centers available in health facilities in communities to improve access and utilization by community members.

The limitation of the study was that it was not possible to sample a higher number Respondents in each Senatorial districts when compared to the estimated population of the state as a result of limited financial resources available and other logistical challenges.

\section{References}

1. Ojonugwa UF (2015) Unraveling the truth about blood donation. Leadership. Link: www.leadership.ng

2. World Health Organization (2002) Proposal to establish World Blood Donor Day. Fifty-Eighth World Health Assembly, Geneva. Link: https://bit.ly/3ANe2LO

3. World Health Organization (2011) Blood Safety. Key global facts and figures. Link: https://bit.ly/3i80DGN

4. Obinna C, Amusat M, Udemba K (2013) Nigeria hit by shortage of voluntary blood donors. Link: https://bit.ly/2Y09H9N

5. World Health Organization (2010) Blood safety and availability. Fact sheet 279

6. Dubey A, Sonker A, Chaurasia R, Chaudhary R (2014) Knowledge, attitude, and beliefs of people in North India regarding blood donation. Blood Transfus 12 21-27. Link: https://bit.ly/3kHG99z

7. Jemberu YA, Esmael A, Ahmed KY (2016) Knowledge, attitude and practice towards blood donation and associated factors among adults in Debre Markos town, Northwest Ethiopia. BMC Hematol 16: 23. Link: https://bit.ly/3CJYEA9

8. Waheed U, Azmaat M, Zaheer HA (2015) Knowledge, attitude and practices towards blood donation in Pakistan: a nationwide survey. Hematological Transfusion International Journal1: 83-86. Link: https://bit.ly/2XPmRWv

9. World Health Organization (2010) Blood safety and donation: a global view. Link: https://bit.ly/3CNtSXo

10. Lacetera N, Macis M (2008) Social image concerns and pro-social behavior IZA Discussion Paper no. 3771. Link: https://bit.ly/3ETrdwT

11. Bir Singh RMP, D’Souza A, Anushyanthan V, Krishna V, Gupta MM, et al. (2002) Knowledge, attitudes and socio-demographic factors differenciating blood donors from non-donors in an Urban Slum of Delhi. Indian Journal of Community Medcine 27: 118-123. Link: https://bit.ly/39CacJe

12. Shan H, Wang JX, Ren FR, Zhang YZ, Zhao HY, et al. (2002) Blood Banking in China. Lancet 360: 1770-1775. Link: https://bit.ly/3o5jlT6

13. Salaudeen AG, Musa OI, Awoyemi AO, Bolarinwa AO, Adegboye AO, et al (2011) Community survey on blood donation practices in a northern state of Nigeria. J Prev Med Hyg 52: 21-25. Link: https://bit.ly/39BruGv

14. Sharma RK, Verma S, Sharma M, Pugazhendi S (2016) Voluntary blood donation: Attitude and practice among Indian Adults. Journal of Community Medicine and Health 3: 436-440.

15. Hassan A, Nasim SHD, Fariba S (2011) Contribution of religion to blood donation: Iran experience. Asian J Transfus Sci 5: 185-186. Link: https://bit.ly/39Gu8uo

16. Maghullu M (2005) Assessing the motivation of blood donors in 28 provinces of Iran. Research Collection of Iranian Blood Transfusion Organization. Iranian Blood Transfusion Research Center Publication 2: 37.

17. Abderrahman BH, Saleh MY (2014) Investigating ,knowledge and attitudes of blood donors and barriers concerning blood donation in Jordan. ProcediaSocial and Behavioral Sciences 116: 2146-2154. Link: https://bit.ly/3u8SbvH

18. Wikipedia (2016) Jehovah's witnesses and blood transfusions. Link: https://en.wikipedia.org/wiki/

19. The Watchtower (2004) Be guided by the living God 22.

20. National Population Commission (2006) Population census. Abuja: National Population Commission. Link: https://bit.ly/3uo75hT

Discover a bigger Impact and Visibility of your article publication with

Peertechz Publications

\section{Highlights}

* Signatory publisher of ORCID

* Signatory Publisher of DORA (San Francisco Declaration on Research Assessment)

- Articles archived in worlds' renowned service providers such as Portico, CNKI, AGRIS, TDNet, Base (Bielefeld University Library), CrossRef, Scilit, J-Gate etc.

* Journals indexed in ICMJE, SHERPA/ROMEO, Google Scholar etc.

* OAI-PMH (Open Archives Initiative Protocol for Metadata Harvesting)

* Dedicated Editorial Board for every journal

* Accurate and rapid peer-review process

* Increased citations of published articles through promotions

* Reduced timeline for article publication

Submit your articles and experience a new surge in publication services (https://www.peertechz.com/submission).

Citation: Peters GE, Oko NI (2021) Evaluation of Factors affecting voluntary blood donation in South-South Nigeria: Focus on Akwa Ibom State. Arch Prev Med 6(1): 007-011. DOI: https://dx.doi.org/10.17352/apm.000028 